Отримано: 19 травня 2018 р.

Прорецензовано: 27 травня 2018 р.

Прийнято до друку: 01 червня 2018 р

e-mail: tanjadolishnja@gmail.com

DOI: 10.25264/2311-5149-2018-9(37)-180-184
Долішня Т. І. Облік податків та податкових платежів: управлінський аспект. Наукові записки Начіонального університету "Острозька академія». Серія «Економіка» : науковий журнал. Острог : Вид-во НаУОА, червень 2018. № 9(37). С. 180-184.

Долішня Тетяна Іванівна,

кандидат економічних наук, доцент, доцент кафедри обліку і аудиту Івано-Франківський національний технічний університет нафти і газу

\title{
ОБЛІК ПОДАТКІВ ТА ПОДАТКОВИХ ПЛАТЕЖІВ: УПРАВЛІНСЬКИЙ АСПЕКТ
}

У статті визначено фактори, щзо впливають на побудову управлінського обліку податків і податкових платежів на підприємствах нафтогазової промисловості. Обгрунтовано подальший розвиток значення управлінського обліку як основної складової інформаційного забезпечення управління господарською діяльністю підприємств. Рекомендовано виокремлення центру податків і податкових платежів із метою вдосконалення організачії управлінського обліку податків і податкових платежів на підприємствах нафтогазової промисловості. Виокреслено перспективи подальших досліджень.

Ключові слова: управлінський облік, податки, податкові платежі, підприємства нафтогазової промисловості.

\section{Долишня Татьяна Ивановна,}

кандидат экономических наук, доиент, доиент кафедры учета и аудита

Ивано-Франковский начиональный технический университет нефти и газа

\section{УЧЕТ НАЛОГОВ И НАЛОГОВЫХ ПЛАТЕЖЕЙ: УПРАВЛЕНЧЕСКИЙ АСПЕКТ}

В статье определены факторы, влияющие на построение управленческого учета налогов и налоговых платежем на предприятиях нефтегазовой промышленности. Обоснованно дальнейшее развитие значения управленческого учета как основной составляющей информационного обеспечения управления хозяйственной деятельностью предприятий. Рекомендовано выделение центра налогов и налоговых платежем с целью усовершенствования организации управленческого учета налогов и налоговых платежем на предприятиях нефтегазовой промышленности. Очерчено перспективы дальнейших исследований.

Ключевые слова: управленческий учет, налоги, налоговые платежи, предприятия нефтегазовой промышленности.

Tatyana Dolishnia,

Ph. D. in Economics, Associate Professor at the Department of Accounting and Auditing, Ivano-Frankivsk National Technical University of Oil and Gas

\section{TAXES AND TAX PAYMENTS ACCOUNTING: MANAGEMENT ASPECT}

The article defines the factors that affect the implementation of taxes and tax payments managerial accounting at oil and gas industry enterprises. The authors substantiate the importance of further development of managerial accounting as the main information support component of enterprises economic activity management. It is recommended to single out center of taxes and tax payments with the purpose of improving the organization of taxes and tax payments managerial accounting at oil and gas industry enterprises. Prospects for further research are outlined.

Keywords: management accounting, taxes, tax payments, enterprises of the oil and gas industry.

Постановка проблеми. Сукупний розмір податкових і дивідендних платежів групи Нафтогаз до державного бюджету у 2017 році склав 106,0 млрд грн, зокрема податок на прибуток на суму 14,3 млрд грн, ПДВ - 30,2 млрд грн, рентні платежі - 33,9 млрд грн, дивіденди - 13,3 млрд грн. Відрахування групи Нафтогаз до бюджету у 2017 році майже у 1,5 рази перевищили платежі за 2016 рік [1].

Надходження від групи Нафтогаз склали близько 14\% загальних доходів державного бюджету у 2017 році. Група Нафтогаз є найбільшим платником податків до державного бюджету України [1].

Перспективи подальшого розвитку підприємств нафтогазової промисловості передбачають потребу вдосконалення управлінського обліку податків і податкових платежів як надійного інформаційного підгрунття для прийняття ефективних управлінських рішень.

Аналіз останніх досліджень і публікацій. Упродовж останніх років проблемам упровадження й організації управлінського обліку на підприємствах, обліку і звітності оподаткування приділялося багато уваги з боку вчених-економістів як українських, так і найближчого зарубіжжя [2; 3; 4; 5$]$. 
Метою статті $є$ дослідження організації управлінського обліку на підприємствах нафтогазової промисловості з метою розвитку іiі та вдосконалення. Незважаючи на значні теоретичні та практичні напрацювання щодо організації управлінського обліку на підприємствах, його податкова складова потребує подальших досліджень, і на сьогодні має актуальне значення. Завданнями є: визначення факторів, що впливають на побудову управлінського обліку податків і податкових платежів на підприємствах нафтогазової промисловості; обгрунтування подальшого розвитку значення управлінського обліку як важливої складової інформаційного забезпечення, зокрема в частині податків і податкових платежів, управління господарською діяльністю підприємств; розробка рекомендацій щодо вдосконалення організації управлінського обліку податків, податкових платежів і подальших напрямів досліджень проблематики.

Виклад основного матеріалу. Управлінський облік податків і податкових платежів, виконуючи інформаційне забезпечення системи управління, $є$ інструментом управління податками та податковими платежами на підприємстві.

Управлінський облік податків і податкових платежів на підприємстві уможливлює досягнення оптимального рівня податкових платежів за умови дотримання норм податкового законодавства. Його основною метою є активний вплив на максимізацію чистого прибутку підприємства при заданих параметрах податкового середовища та ринкової кон'юнктури, а не абсолютна мінімізація податкових платежів.

Відповідно до Закону України «Про бухгалтерський облік та фінансову звітність в Україні» підприємство самостійно розробляє систему і форми внутрішньогосподарського (управлінського) обліку, звітності і контролю господарських операцій, визначає права працівників на підписання бухгалтерських документів тощо [6].

Визначити чіткий універсальний порядок організації управлінського обліку для всіх підприємств нафтогазової промисловості практично не можливо, однак можна виділити ряд зовнішніх і внутрішніх факторів, що впливають на його побудову, а саме:

- відповідність цілям і завданням діяльності підприємства;

- вплив особливостей технологічних процесів на підприємствах нафтогазової промисловості;

- вплив важкопрогнозованих природно-геологічних, географо-економічних та інших галузевих факторів;

- оптимізація структури та рівня деталізації бази бухгалтерських даних, які використовують менеджери;

- зіставлення із загальними принципами формування організаційної структури управління підприємством тощо.

Організація управлінського обліку в частині податків і податкових платежів $є$ системою принципів і методів розробки та реалізації (ув'язки) управлінських рішень, пов'язаних з обгрунтуванням вибору податкової системи, розрахунком податкових платежів, постійним контролем за їх здійсненням. Завдання - забезпечення розробки податкової політики підприємства залежно від його економічної стратегії та напрямів діяльності, а також визначення такої системи податків, яка б дала змогу отримувати найбільші прибутки, оптимізуючи податкові платежі до державного бюджету.

Ефективність системи оподаткування, а відтак і управлінської системи в податковій сфері, зумовлює необхідність якісних перетворень, які стосуються системи управлінського обліку, а саме у сфері податкових розрахунків і податкової звітності. Власне, для отримання більш ефективних механізмів прийняття управлінських рішень, важливу роль відіграє якість інформації, одержаної користувачами. Так, прийняття рішень базується на інформації, яка повинна мати завершений характер, бути корисною та відображати реальний стан діяльності підприємства на конкретний час. Взаємовідносини між управлінським обліком та оподаткуванням не досягають усіх поставлених цілей у сфері оподаткування та несуть значні витрати для суб'єктів господарювання. А тому, як і будь-які інші витрати платника, податкові платежі $\epsilon$ об'єктом бюджетування (планування) й управління.

Одним із важливих елементів організації управлінського обліку є виділення в структурі суб'єкта господарювання центрів відповідальності (Responsibility Center), тобто сегментів діяльності, в межах яких встановлено персональну відповідальність менеджера за контрольовані ним показники діяльності.

Так, у системі управління вищий керівник має контролювати й оцінювати роботу менеджерів нижчого рівня, а вони, своєю чергою, повинні здійснювати самоконтроль та інформувати вище керівництво про результати діяльності. Створення та функціонування таких центрів відповідальності дозволяє системно здійснювати облікові та контрольно-аналітичні процедури в межах діяльності центрів відповідальності, забезпечуючи підзвітність їх функціонування.

У міжнародній практиці управлінського обліку, залежно від характеру відповідальності менеджерів, виділяють чотири типи центрів відповідальності [2, с. 407]:

- центр витрат (Cost Center) - керівник якого контролює витрати, але не контролює доходів й інвестицій в активи центру; 
- центр доходів (Revenue Center) - керівник якого контролює доходи, але не контролює витрати на виробництво продукції (робіт, послуг) або придбання товарів, що реалізуються, та інвестиції в активи центру;

- центр прибутку (Profit Center) - керівник якого контролює витрати та доходи, але не контролює інвестиції в активи центру;

- центр інвестицій (Investment Center) - керівник якого контролює витрати, доходи й інвестиції в активи центру.

Упровадження будь-якого нового податку, чи зміни ставки чинного податку, безсумнівно, впливають на прийняття управлінських рішень. Це виражається в різних значеннях фінансового результату до оподаткування і після.

Сьогодні окремими вченими [7] розроблено методики включення податкових витрат у процес управління витратами. Аналіз цих методик указав на існування труднощів щодо розподілу більшості податків безпосередньо за тим чи іншим центром. Це стосується, наприклад, таких податків: на прибуток, ПдВ тощо. Вважають, що розподіл ПДВ пропорційно чисельності працюючих чи фонду заробітної плати $€$ цілком виправданим. Щодо податку на прибуток, то тут може бути застосована практично будь-яка база. Тут не може бути загальних рекомендацій, оскільки необхідно, насамперед, враховувати специфіку діяльності підприємств [7, с. 27].

Для бурових підприємств, наприклад, можна застосовувати, на нашу думку, такі бази розподілу: прямі витрати, верстато-дні роботи бурового обладнання, обсяг проходки, обсяг спожитої електроенергії, обсяг спожитої пари, об'єм промивальної рідини, відпрацьовані години тощо. Для газотранспортних - обсяги транспортування природного газу тощо.

Водночас деякі податки за своєю природою мають таку податкову базу, що їх можна більш-менш обгрунтовано віднести до того чи іншого центру витрат. Це податки, базою для обчислення яких є заробітна плата, саме вони можуть формувати трудові витрати. Використовуючи отримані дані щодо розподілу податків за центрами витрат, необхідно застосувати стандартні для управлінського обліку методи, а саме: витрати допоміжних та обслуговуючих підрозділів необхідно відносити на витрати виробничих підрозділів.

Якщо допоміжні й обслуговуючі підрозділи надають послуги не тільки виробничим підрозділам, але взаємні послуги один одному, тоді розподіл витрат ускладнюється. У цьому випадку можуть застосовувати такі методи розподілу витрат [2, с.106-108]:

- прямий розподіл, який передбачає списання витрат допоміжних та обслуговуючих підрозділів безпосередньо на витрати виробничих підрозділів. А взаємні послуги цих підрозділів не беруть до уваги;

- послідовний розподіл витрат передбачає розподіл витрат кожного допоміжного та обслуговуючого підрозділу послідовно щодо виробничих підрозділів та інших підрозділів. Водночас перший обслуговуючий підрозділ, витрати якого розподілено, не повинен містити витрати іншого підрозділу, навіть якщо це йому вигідно.

- метод взаємних послуг передбачає розподіл витрат допоміжних та обслуговуючих підрозділів послідовно з урахуванням взаємних послуг;

- метод одночасного розподілу витрат допоміжних та обслуговуючих підрозділів передбачає розподіл взаємних послуг шляхом розв’язання рівнянь.

Загалом використання прямого чи поетапного обчислення залежить від специфіки діяльності підприємства чи переваг менеджера.

На нашу думку, з метою покращення управління податками та податковими платежами на підприємствах нафтогазової промисловості доцільно виокремити центр податків і податкових платежів. Наявність прямого зв'язку між витратами, доходами дає змогу керівнику підрозділу контролювати нарахування та сплату податків і податкових платежів підприємства (рис. 1) [8].

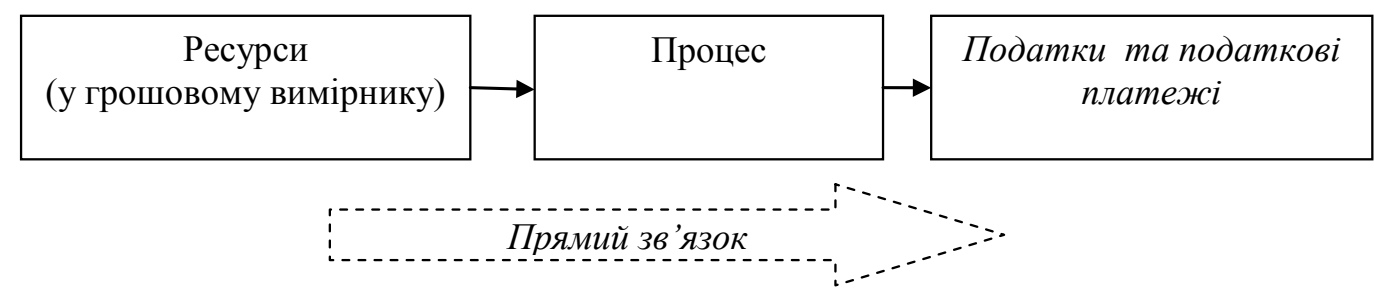

Рис. 1. Схема центру податків та податкових платежів

Джерело: [8]. 
У межах визначених даним центром відповідальності об’єктами управлінського обліку стануть господарські операції, які враховують під час визначення зобов'язань підприємства нафтогазової промисловості за податками та податковими платежами відповідно до чинного Податкового кодексу України [9]. Зокрема, Управління бурових робіт нараховують і сплачують такі податки та збори: податок на додану вартість, екологічний податок, податок на майно, податок на прибуток, податок на доходи фізичних осіб, військовий збір.

Рекомендації щодо організації обліку за центром податків та податкових платежів на бурових підприємствах, зокрема, наведено в таблиці 1.

Таблиия 1

Організація обліку в розрізі податків та податкових платежів

\begin{tabular}{|c|c|c|c|}
\hline \multicolumn{4}{|c|}{ Податок на доходи фізичних осіб } \\
\hline \multicolumn{4}{|c|}{ Узагальнено облік ПДФО за иеентрами відповідальності - I рівень } \\
\hline $\begin{array}{c}\text { Керівництво } \\
\text { підприємства }\end{array}$ & \multicolumn{3}{|c|}{ підприємство } \\
\hline \multicolumn{4}{|c|}{ Узагальнено облік ПДФО за ичентрами відповідальності - ІІ рівень } \\
\hline Начальники цехів & Вишкомонтажний цех & $\begin{array}{l}\text { Інженерно-технологічна } \\
\text { служба }\end{array}$ & База виробничого обслуговування \\
\hline \multicolumn{4}{|c|}{ Узагальнено облік ПДФО за ичентрами відповідальності - ІІІ рівень } \\
\hline Майстри & Бригада робітників & Бригада робітників & Бригада робітників \\
\hline \multicolumn{4}{|c|}{ Податок на прибуток } \\
\hline \multicolumn{4}{|c|}{ Узагальнено облік податку на прибуток за иеентрами відповідальності - I рівень } \\
\hline $\begin{array}{l}\text { Керівництво } \\
\text { підприємства }\end{array}$ & \multicolumn{3}{|c|}{ підприємство } \\
\hline \multicolumn{4}{|c|}{ Узагальнено облік податку на прибуток за ичентрами відповідальності - II рівень } \\
\hline Начальники цехів & Вишкомонтажний цех & $\begin{array}{l}\text { Інженерно-технологічна } \\
\text { служба }\end{array}$ & База виробничого обслуговування \\
\hline \multicolumn{4}{|c|}{ Узагальнено облік податку на прибуток за иеентрами відповідальності - III рівень } \\
\hline Майстри & Бригада робітників & Бригада робітників & Бригада робітників \\
\hline \multicolumn{4}{|c|}{ Екологічний податок } \\
\hline \multicolumn{4}{|c|}{ Узагальнено облік екологічного податку за ијентрами відповідальності - I рівень } \\
\hline $\begin{array}{l}\text { Керівництво } \\
\text { підприємства }\end{array}$ & \multicolumn{3}{|c|}{ підприємство } \\
\hline \multicolumn{4}{|c|}{ Узагальнено облік екологічного податку за чентрами відповідальності - II рівень } \\
\hline Начальники цехів & Вишкомонтажний цех & $\begin{array}{l}\text { Інженерно-технологічна } \\
\text { служба }\end{array}$ & База виробничого обслуговування \\
\hline \multicolumn{4}{|c|}{ Узагальнено облік екологічного податку за ичентрами відповідальності - III рівень } \\
\hline Майстри & Бригада робітників & Бригада робітників & Бригада робітників \\
\hline і т.д. & & & \\
\hline
\end{tabular}

Джерело: власна розробка.

Інформація, необхідна для прийняття рішень щодо податкового бюджетування (планування) незалежно від внутрішньої структури і системи управління підприємством, міститься в даних податкового, бухгалтерського й управлінського обліку. Однак тільки в межах управлінського обліку можна вирішити завдання щодо управління податками. По-перше, управлінський облік здійснюється винятково всередині самого підприємства, водночас як інші види обліку або визначені правилами, встановленими ззовні, або передбачають врахування подій, що відбуваються в зовнішньому середовищі. По-друге, управлінський облік надає дані в оперативному порядку вчасно, саме тоді, коли ці дані потрібні для прийняття рішень.

Управлінський облік $\epsilon$ інформаційним підгрунтям для прийняття ефективних управлінських рішень щодо управління податками та податковими платежами. I в такий спосіб, на нашу думку, нівелює проблеми, які можуть виникати в підприємства під час організації податкового обліку.

Висновки. Отже, організація управлінського обліку податків і податкових платежів має надзвичайно важливе значення, бо без дохідливої, доречної, достовірної та порівнюваної інформації було б неможливим управління податками та податковими платежами на підприємствах нафтогазової промисловості. На його побудову впливає цілий ряд факторів - це відповідність цілям і завданням діяльності підприємства, вплив важкопрогнозованих природно-геологічних, географо-економічних та інших галузевих факторів тощо.

Для вдосконалення організації управлінського обліку рекомендовано виокремлення центру податків та податкових платежів на підприємствах нафтогазової промисловості.

Перспективи подальших досліджень полягають у поглибленому вивченні системи бюджетування 3 метою розробки регламенту формування системи бюджетування (форм бюджетів і звітів у частині податків і податкових платежів) для впровадження в систему інформаційної підтримки бюджетування. 


\section{Література:}

1. Офіційний сайт НАК Нафтогаз [Електронний ресурс]. - Режим доступу: http://www.naftogaz.com.

2. Голов С. Ф. Управлінський облік [текст]: підручник / С. Ф. Голов. - К. : Лібра, 2003. - 704 с.

3. Управлінський облік [текст]: підручник /Л. В. Нападовська; Київ.нац. ун-т ім. Т. Г. Шевченка. - 2-ге вид., доопрацьов. та доп. - К.: КНТЕУ, 2010. - 647 с.

4. Левицька С. О. Інформаційна складова податкового менеджменту на макрорівні в контексті сталого національного розвитку / С. О. Левицька, О. О. Осадча // Бізнесінформ, 2014. - № 5. - Режим доступу: httр:// irbis-nbuv.gov.ua.

5. Палий В. Ф. Развитие методологии управленческого учета / В.Ф.Палий //Бухгалтерский учет. 2004. - №12. - С. 52-55.

6. Про бухгалтерський облік і фінансову звітність в Україні [Електронний ресурс]: Закон України від 16 лип. 1999 р. № 996-XI. - Режим доступу: http://search.ligazakon.ua. - Заголовок з екрану.

7. Болдуєва О. В. Упорядкування податкових платежів на підприємстві / О. В. Болдуєва // Держава та регіони, серія: Економіка та підприємство. - Запоріжжя, 2009. - № 1.- С. 25-29.

8. Долішня Т. І. Облік за центрами відповідальності на газотранспортних підприємствах / Т. І. Долішня // Економіка та управління: сучасний стан і перспективи розвитку (Одеса, 23-24 листопада 2017 року): Матеріали III Міжнародної науково-практичної конференції, Одеса, 2017. - С. 182-185.

9. Податковий кодекс України від 02 грудн. 2010 р. за № 2755-УІ [Електронний ресурс]. - Режим доступу: http://search.ligazakon.ua. 